Kumawula, Vol. 3, No.3, Desember 2020, Hal 416 - 423 DOI: https://doi.org/10.24198/kumawula.v3i3.27469 ISSN 2620-844X (online)

Tersedia online di http://jurnal.unpad.ac.id/kumawula/index

\title{
PEMETAAN SOSIOLOGIS DESA CINTARATU KABUPATEN PANGANDARAN
}

\author{
Cecep Safa'atul Barkah ${ }^{1}$, Marsha Aulia Hakim², Farisadri Fauzan ${ }^{3}$ \\ ${ }^{1}$ Departemen Ilmu Administrasi Bisnis, Universitas Padjadjaran \\ ${ }^{2}$ Departemen Ilmu Administrasi Bisnis, Universitas Padjadjaran \\ ${ }^{3}$ Departemen Ilmu Administrasi Bisnis, Universitas Padjadjaran \\ *Korespondensi : cecep.barkah@unpad.ac.id
}

\begin{abstract}
Cintaratu is one of the villages that has a strategic position in the Pangandaran Regency. There are many improvements that needs to be done to maximize the village's potential. The Community Organizations within the village must be in harmony to create imp actful programs for the people of Cintaratu. A social mapping with Participatory Rural Appraisal (PRA) analyzes how the community organizations perform. By using the PRA approach, Researchers can create a two-way communication. They could dig deeper into social life in Cintaratu by activating community participation. The research uses the descriptive method with a qualitative approachthe data collected by observing, in-depth interview, and documentation. The sampling uses the purposive sampling method. There are twelve community organizations identified in this research. Most of the organizations are creating an impact on society, while only three organizations are not. The majority of the poor people in Cintaratu works as farm-workers. They feel the government's programs are not suitable and misdirected. The local government needs to create more impactful policy for the people of Cintaratu.
\end{abstract}

\begin{abstract}
ABSTRAK
Desa Cintaratu merupakan salah satu desa yang memiliki posisi cukup strategis di wilayah Kabupaten Pangandaran karena dekat dengan pusat pemerintahan Kabupaten Pangandaran yaitu Kecamatan Parigi. Namun masih banyak sekali hal yang perlu diperbaiki untuk dapat memaksimalkan potensi desa, diperlukan peran dari berbagai organisasi yang ada di Desa Cintaratu untuk dapat selaras memberikan dampak pada peningkatan kehidupan masyarakat. Perlu diadakan pemetaan sosial untuk mengetahui sejauh mana dampak dari berbagai organisasi masyarakat serta kondisi sosial-budaya di Desa Cintaratu. Pendekatan Participatory Rural Appraisal digunakan sehingga peneliti dapat menggali lebih dengan mengajak masyarakat berpartisipasi dalam pembangunan desanya. Penelitian ini dilakukan secara deskriptif dengan pendekatan kualitatif. Sampling dilakukan dengan cara purposive sampling dan data dikumpulkan melalui metode observasi partisipatif, wawancara mendalam, dan dokumentasi. Dari hasil observasi dan wawancara diketahui ada 12 organisasi masyarakat di Desa Cintaratu. Sebagian besar dari organisasi masyarakat tersebut sudah dirasakan dampaknya, namun terdapat tiga organisasi yang masih belum terasa dampak dari keberadaannya. Hal ini perlu diperhatikan oleh pengurus organisasi serta Pemerintah Desa Cintaratu. Dari segi masyarakat yang kurang mampu diketahui bahwa Sebagian besar dari mereka merupakan buruh tani dan program yang diberikan untuk masyarakat miskin dirasa masih kurang sesuai dan masih banyak yang tidak tepat sasaran Perlu adanya suatu kebijakan dari pengambil keputusan setempat untuk dapat membuat suatu program yang memiliki dampak dan secara nyata dirasakan oleh masyarakat desa.
\end{abstract}

Kata Kunci: Pemetaan Sosial; Participatory Rural Appraisal; Organisasi Kemasyarakatan

\section{PENDAHULUAN}

Menurut Handoyo dan Sudrajat (2016), Pemetaan sosial adalah suatu aktivitas yang dilakukan untuk dapat memahami kondisi sosial yang terjadi pada masyarakat lokal. Setiap masyarakat yang berbeda memiliki kondisi sosial yang berbeda sehingga perlu dipahami khususnya oleh para pengambil keputusan. Kegiatan pemetaan ini sangat bermanfaat bagi para pengambil keputusan untuk dapat membuat suatu kebijakan yang tepat sesuai 
dengan kondisi sosial yang terjadi. Pemetaan sosial dilaksanakan untuk memahami kondisi sosial masyarakat lokal. Pemahaman yang baik terkait kondisi sosial diharapkan dapat menciptakan kebijakan yang tepat sasaran dan berdampak secara nyata.

Desa Cintaratu merupakan desa yang berada pada daerah administratif Kecamatan Parigi Kabupaten Pangandaran. Sebagai salah satu desa yang berada pada ibukota Kabupaten Pangandaran, Desa Cintaratu memiliki letak yang sangat strategis. Menurut data yang diperoleh dari website resmi Desa Cintaratu, luas wilayah Desa Cintaratu adalah 1029 На dan terbagi menjadi 5 Dusun, 10 RW, dan 34 RT. Lima dusun tersebut adalah Dusun Bontos (2 RW dan 6 RT), Dusun Cintasari (2 RW 9 RT), Dusun Sukamanah (2 RW dan 6 RT), Dusun Panglajan (3 RW dan 8 RT), dan Dusun Gunung Tiga (1 RW dan 5 RT).

Tabel 1. Rincian Luas Desa Cintaratu

\begin{tabular}{|c|c|c|}
\hline No. & Uraian & $\begin{array}{c}\text { Luas } \\
\text { (Ha) }\end{array}$ \\
\hline 1 & Sawah dan Ladang & 288,61 \\
\hline 2 & Bangunan Umum & 15,69 \\
\hline 3 & Pemukiman/Perumahan & 200 \\
\hline 4 & Pemakaman/Pekuburan & 15,10 \\
\hline 5 & Pertokoan/Perdagangan & 3,56 \\
\hline 6 & Perkantoran & 1,80 \\
\hline 7 & Tanah Wakaf & 5,60 \\
\hline 8 & Pekarangan & 17,00 \\
\hline 9 & Tegalan & - \\
\hline 10 & Perkebunan Negara & - \\
\hline 11 & Perkebunan Rakyat & 116,72 \\
\hline 12 & Tempat Rekreasi & 17 \\
\hline 13 & Hutan & 23 \\
\hline 14 & Lain-Lain & 324,92 \\
\hline \multicolumn{3}{|c|}{ Jumlah } \\
\hline
\end{tabular}

Sumber:

https://www.cintaratu.desa.id/geografis/

Adapun batas-batas dari Desa Cintaratu adalah sebagai berikut:

- Utara: berbatasan dengan Desa Selasari Kecamatan Parigi

- Timur: berbatasan dengan Desa Bojong Kecamatan Parigi
- Selatan: berbatasan dengan Desa Cintakarya Kecamatan Parigi

- Barat: berbatasan dengan Desa Selasari Kecamatan Parigi

Desa Cintaratu terletak pada ketinggian ratarata 119 meter dari permukaan laut. Sebagian besar wilayah Desa Cintaratu adalah lereng berbukit dengan tingkat kemiringan rata-rata $30^{\circ}$ dan dengan bentuk permukaan tanah berbukit $+90 \%$. Desa Cintaratu ini memiliki curah hujan rata-rata $200 \mathrm{~mm}$ dan suhu udara rata-rata $32-34^{\circ} \mathrm{C}$. Jumlah penduduk di Desa Cintaratu adalah sebanyak 3.718 jiwa dengan kepala keluarga sejumlah 1387 KK. Tingkat kepadatan penduduk per meter perseginya yaitu 15 jiwa dengan laju pertumbuhan penduduk sebesar 2\% - 3\% per tahun. Adapun jumlah penduduk tersebut terdistribusi menjadi 1.846 penduduk laki-laki dan 1.872 penduduk perempuan.

Pendekatan yang digunakan pada pelaksanaan pemetaan sosial ini adalah Participatory Rural Appraisal (PRA). Menurut Chambers (1994), Pendekatan Participatory Rural Appraisal berkembang dan menyebar begitu cepat. Pada awal 1994, penggunaan metode PRA dapat dilakukan pada 4 sektor utama yaitu:

a. Pengelolaan Sumber Daya Alam

b. Pertanian

c. Kemiskinan dan Program Sosial

d. Kesehatan dan Ketahanan Pangan

Menurut Handayani (2009), Penggunaan PRA adalah untuk mengupayakan tumbuhnya pemberdayaan masyarakat sehingga diharapkan berdampak pada munculnya proses partisipasi aktif, baik teknis maupun politis dari masyarakat yang menjadi kelompok sasaran dalam keseluruhan program kegiatan. Dari partisipasi aktif masyarakat ini, maka masyarakat diharapkan pula dapat membuat rencana tindakan yang layak (Darwis, Resnawaty, \& Nuriyah, 2020).

Prinsip-prinsip Penerapan PRA (Adimihardja \& Hikmat, 2003 seperti dikutip oleh Handayani, 2009) meliputi: 
1. Masyarakat dipandang sebagai subjek bukan objek.

2. Peneliti memosisikan dirinya sebagai insider bukan outsider.

3. Lebih baik mendekati benar daripada benar-benar salah untuk menentukan parameter yang standar.

4. Masyarakat yang membuat peta, model, diagram, pengurutan, memberi angka/nilai, mengkaji/menganalisis, memberikan contoh, mengidentifikasi dan menyeleksi prioritas masalah, menyajikan hasil, mengkaji ulang dan merencanakan kegiatan aksi.

5. Pemberdayaan dan partisipatif masyarakat dalam menentukan indikator sosial (indikator evaluasi partisipatif).

Pada penelitian ini, peneliti berfokus kepada 2 (dua) sektor yaitu pertanian serta kemiskinan dan program sosial. Karena berdasarkan pengamatan secara kasar, ditemukan bahwa penduduk Desa Cintaratu sendiri cukup banyak yang memiliki mata pencaharian pada sektor pertanian dan perlu diketahui apakah terdapat program sosial yang mendukung peningkatan kesejahteraan masyarakat dan apakah dampak program tersebut terasa nyata oleh masyarakat. Peneliti ikut aktif dalam berbagai kegiatan yang ada dan berbaur bersama dengan masyarakat desa Desa Cintaratu untuk dapat menggali lebih dalam terkait kedua sektor tersebut. Dengan ikut aktif pada kegiatan masyarakat, harapannya masyarakat dapat mengatakan dengan jujur apa yang terjadi pada sektor yang diteliti, juga peneliti dapat melakukan observasi langsung. Adapun penelitian ini sifatnya masih pemetaan sehingga merupakan tahap awal dari penemuan suatu model yang dapat menjadi suatu masukan bagi pengambil keputusan, dalam hal ini adalah Pemerintah Desa Cintaratu.

\section{METODE}

Penelitian ini dilakukan secara deskriptif dengan menggunakan pendekatan secara kualitatif. Penelitian kualitatif menurut Strauss dan Corbin (2003) adalah jenis penelitian yang hasil temuannya tidak didapatkan dengan melakukan prosedur statistika atau bentuk perhitungan lainnya. Menurut Sugiyono (2008) penelitian kualitatif adalah metode penelitian yang berlandaskan pada filsafat positivisme, dimanfaaatkan untuk meneliti pada kondisi objek yang sifatnya alamiah, dimana peneliti merupakan instrumen kunci pada penelitian, Pada penelitian ini sampel data diambil menggunakan beberapa metode yaitu:

1. Observasi/Pengamatan

Menurut Bungin (2007) ada dua tipe observasi, yaitu observasi tidak langsung dan observasi partisipatif. Observasi tidak langsung merupakan observasi dimana peneliti tidak masuk ke dalam masyarakat tersebut namun hanya mengamati dari jarak jauh dibantu dengan media lain seperti kamera. Sedangkan observasi partisipatif adalah pengamatan langsung dengan melibatkan diri dalam kegiatan masyarakat yang diteliti. Pada penelitian ini dilakukan observasi partisipatif karena menyesuaikan dengan pendekatan participatory rural appraisal.

2. Wawancara

Wawancara merupakan kegiatan melakukan tanya jawab dan berdiskusi dengan subjek penelitian. Menurut Bungin (2007), terdapat dua tipe wawancara, yaitu wawancara terstruktur dan wawancara mendalam. Pada penelitian ini dilakukan wawancara mendalam untuk mengetahui secara jelas berbagai fenomena sosial yang terjadi di lingkungan masyarakat Desa Cintaratu.

3. Dokumentasi

Menurut Sugiyono (2008), hasil pengumpulan data dari wawancara dan observasi dapat lebih kredibel apabila menyertakan suatu dokumentasi 
(Sugiyono, 2009: 329). Sehingga pada penelitian ini kegiatan wawancara dan observasi diabadikan dengan dokumentasi kegiatan.

Sampling atau pemilihan sampel pada penelitian ini dilakukan secara purposive sampling. Purposive sampling adalah teknik pengambilan sampel sumber data dengan melalukan pertimbangan tertentu (Sugiyono, 2008), misalnya orang tersebut dianggap paham dan dapat memberikan informasi yang relevan dan dibutuhkan pada penelitian ini. Pada penelitian ini sampel yang diambil adalah tokoh-tokoh masyarakat karena dianggap cukup paham dengan fenomena sosial yang terjadi di Desa Cintaratu. Sedangkan analisis data kualitatif yang didapat dilakukan dengan menggunakan pendekatan yang dilakukan Huberman dan Miles (1994).

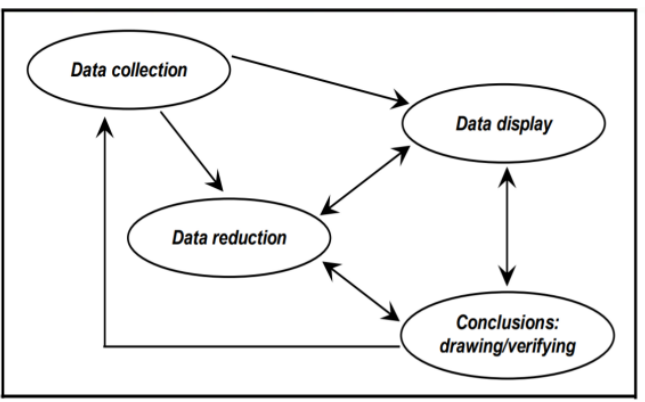

Gambar 1. Teknik Analisis Data (Huberman dan Miles, 1994)

\section{HASIL DAN PEMBAHASAN}

\section{a. Tipologi Masyarakat Desa dan Pola Pemukiman di Desa}

Sebagian besar penduduk Desa Cintaratu memiliki mata pencaharian sebagai petani, baik memiliki lahan sendiri maupun menjadi buruh tani. Sehingga jika diklasifikasikan, maka Desa Cintaratu merupakan tipe Desa Swadaya dimana desa ini memiliki ketergantungan terhadap hasil alam berupa pertanian serta kedudukan seseorang masih dinilai berdasarkan keturunan dan luasnya kepemilikan tanah.
Desa Cintaratu sendiri terdiri dari 5 (lima) dusun yang memiliki pola pemukiman di mana tempat tinggal masyarakat desa dikelilingi oleh sawah ladang masyarakat desa. Lahan untuk pengembangan usaha tani maupun penggembalaan hewan ternak umumnya berada di belakang lokasi pemukiman. Rumah di Desa Cintaratu ditata atau dibangun berbaris lurus mengikuti suatu garis tertentu menyilang atau menyusur jalan utama. Sehingga, nampak pada setiap dusun bangunan hanya berada di sekitar jalan utama. Bagian yang tidak dilewati jalan utama umumnya berupa lahan pertanian dan perkebunan.

\section{b. Stratifikasi Sosial Masyarakat Desa}

Adapun di Desa Cintaratu, stratifikasi sosial masyarakat desa ditentukan oleh:

1. Berperan sebagai Opinion Leader (orang yang opininya didengar masyarakat).

2. Aktif di tengah masyarakat dan penggerak masa.

3. Memiliki tingkat ekonomi yang tinggi.

4. Berperan dalam bidang keagamaan di tengah masyarakat.

5. Merupakan perangkat pemerintahan.

6. Sesepuh (orang yang dituakan di masyarakat).

Sehingga orang yang dianggap memiliki kedudukan yang tinggi di Desa Cintaratu adalah kepala desa dan perangkat desa, tokoh keagamaan, tokoh adat, dan orang dengan tingkat ekonomi yang tinggi.

\section{c. Petani di Desa Cintaratu}

Seperti dituliskan pada poin a, masyarakat Desa Cintaratu sebagian besar merupakan petani dengan produk unggulan berupa padi, jagung, kacang tanah, cabe merah, cabe rawit, mentimun, terong, dan kacang panjang. Sebagian besar hasil panen yang dihasilkan oleh petani Desa Cintaratu masih dijual ke wilayah terdekat, baik di dalam Desa Cintaratu sendiri maupun 
pasar-pasar terdekat dari wilayah Desa Cintaratu. Para petani di Desa Cintaratu sendiri ada yang menjual melalui saluran penjualan sendiri, melalui kelompok tani/koperasi, ataupun melalui pemborong.

\section{d. Lembaga Sosial di Desa}

Setelah dilakukan penelitian di Desa Cintaratu, terdapat beberapa lembaga yang ada di Desa Cintaratu seperti digambarkan pada Gambar 1 di bawah. Terdapat setidaknya 12 lembaga dari berbagai fungsi yanag dianggap berpengaruh maupun tidak berpengaruh terhadap kehidupan masyarakat Desa Cintaratu.



\section{Gambar 2. Pengaruh Lembaga Bagi Masyarakat Desa Cintaratu}

(Sumber: Data Diolah)

Berdasarkan data yang didapatkan, dari 12 lembaga tersebut, Pos Penyuluhan Desa (Posluh), Pemberdayaan Kesehatan Keluarga (PKK), dan Badan Usaha Milik Desa (Bumdes) adalah lembaga yang dirasa masih kurang berpengaruh bagi masyarakat Desa Cintaratu. Mungkin saja program-program lembaga tersebut masih belum menyentuh masyarakat Desa Cintaratu secara keseluruhan. Sehingga, diperlukan peningkatan kinerja dari lembaga-lembaga tersebut agar program yang dihasilkan kedepannya dapat lebih bermanfaat bagi masyarakat Desa Cintaratu. Sebaliknya, di bidang kesehatan, Pusat Kesehatan Desa (Puskesdes) dan Pos Pelayanan Terpadu (Posyandu) dirasakan sangat berpengaruh bagi masyarakat Desa Cintaratu, begitu pula dengan lembaga keagamaan dan pendidikan. Selain itu, terdapat pula Badan Permusyawaratan Desa (BPD) sebagai salah satu lembaga yang memiliki peran besar bagi masyarakat terutama dengan adanya pembangunan infrastruktur. Hal ini memudahkan masyarakat untuk mencapai berbagai akses distribusi. Beberapa lembaga lainnya tidak dianggap berpengaruh, terutama Pos Penyuluhan Desa karena berbagai penyuluhan yang dilakukan tidak memberikan dampak besar bagi masyarakat. Sebagian besar masyarakat mengharapkan program yang dapat langsung dipraktikkan dan memberikan dampak langsung bagi kesejahteraan mereka.

\section{e. Perubahan Sosial Budaya di Desa}

Pada lembaga masyarakat, sangat terlihat bahwa terdapat perubahan sosial. Hal ini terjadi karena terdapat dukungan dari pemerintah dalam infrastruktur desa. Salah satu aspek yang paling berubah adalah dalam aspek berkendara. Terjadi perubahan negatif maupun positif dalam hal ini. Salah satu perubahan negatif yang terjadi yaitu dari cara berkendara anak muda yang tidak mengikuti aturan lalu lintas dengan baik seperti ngebut di jalanan atau tidak menggunakan helm. Selanjutnya, dampak positif yang dirasakan adalah masyarakat dimudahkan untuk mencapai akses tertentu dengan kendaraannya karena sebelumnya jalanan tidak berupa aspal seperti sekarang.

Pada aspek budaya yang paling terasa perubahannya adalah aspek interaksi masyarakat, dimana masyarakat lebih sering bergotong royong, bekerjasama dan bersosialisasi akibat dari adanya program yang dibuat oleh pemerintah. Pada aspek lain seperti pendatang yang menetap dan wisatawan tidak membuat perubahan besar bagi masyarakat karena interaksi masyarakat dengan wisatawan sangat jarang terjadi. 


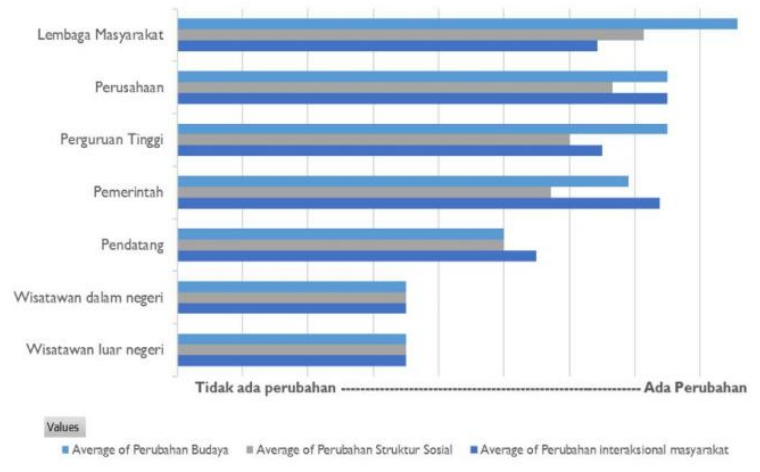

Gambar 3. Perubahan Bagi Masyarakat

(Sumber: Data Diolah)

Wisatawan dalam negeri maupun luar negeri terlihat belum memiliki peran apapun bagi masyarakat karena kedatangannya hanya untuk mengunjungi Jojogan sebagai salah satu destinasi wisata di sana. Namun memang terdapat beberapa pendatang yang bermukim di Desa Cintaratu dan telah memberikan atau peningkatan secara ekonomi.

Selanjutnya, Universitas Padjadjaran (Unpad) sendiri yang telah bekerja sama dengan Pemerintah Provinsi Jawa Barat dan Pemerintah Kabupaten Pangandaran, menyelenggarakan Program Studi di Luar Kampus Utama (PSDKU) bertempat di Desa Cintaratu (Sukoco, Fordian, \& Rusdin, 2020). Penyelenggaraan PSDKU di Desa Cintaratu ini memiliki peran penting dalam keilmuan bagi masyarakat setempat terutama pada aspek kewirausahaan. Masyarakat merasakan dampaknya sehingga termotivasi untuk menjadi pengusaha. Meskipun demikian, menurut hasil wawancara, masyarakat berharap adanya program lain yang dapat langsung diimplementasikan khususnya pada bidang pertanian karena Desa Cintaratu sendiri jika dilihat dari sisi jumlah pekerjaan yang dilakukan sebagian besar adalah petani.

Pemerintah Desa dalam hal ini telah memiliki berbagai program yang telah dilaksanakan, mulai dari pertanian, pemberdayaan, pendidikan, kewirausahaan. Namun, dari hasil wawancara yang dilakukan didapatkan bahwa berbagai program yang dilaksanakan ini tidak terlalu terasa dampaknya bagi masyarakat. Oleh karena itu, diperlukan adanya program yang dibuat untuk jangka panjang yang disertai dengan pengawasan sampai evaluasi yang baik.
Evaluasi sebuah program akan memberikan informasi lebih bagi pembuat program untuk mengetahui dampak yang diberikan setelah

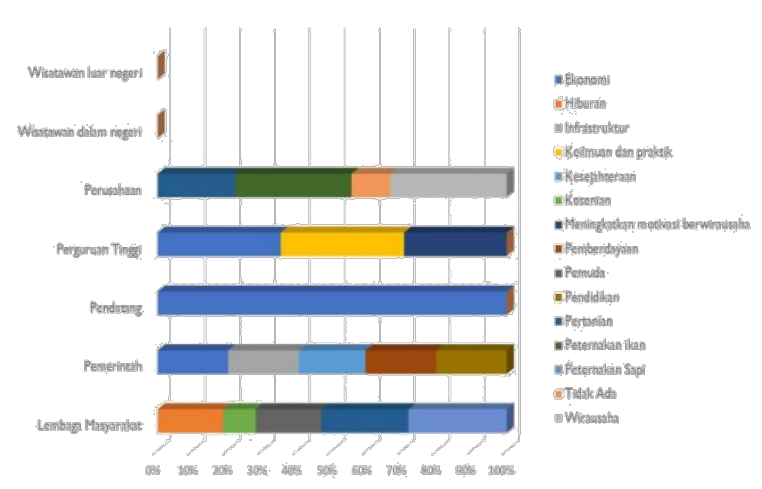

program tersebut selesai dilaksanakan.

\section{Gambar 4. Stakeholder dan Bentuk Peran}

(Sumber: Data Diolah)

\section{f. Kemiskinan di Desa}

Dari hasil wawancara dan observasi yang dilakukan, terungkap bahwa pekerjaan yang dilakukan oleh sebagian besar masyarakat tidak mampu di Desa Cintaratu adalah bekerja sebagai buruh tani, namun terdapat juga yang bekerja serabutan atau bahkan tidak bekerja.

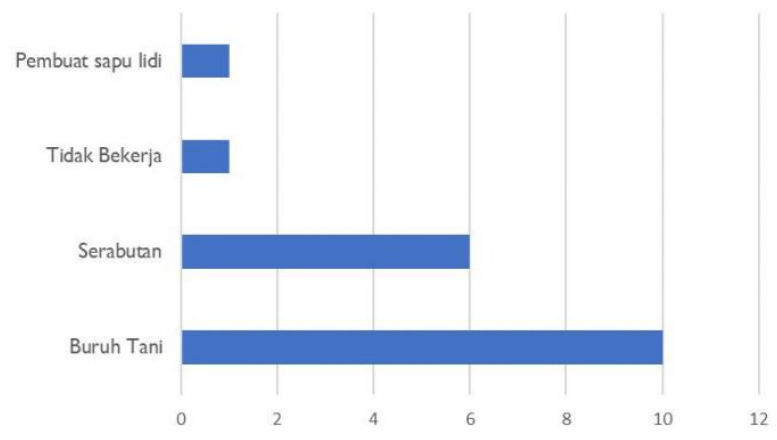

\section{Gambar 5. Pekerjaan Masyarakat Tidak Mampu di Desa Cintaratu \\ (Sumber: Data Diolah)}

Berdasarkan hasil wawancara kepada masyarakat yang kurang mampu, program yang mereka harapkan adalah adanya program pemberian barang-barang pokok (Sembako) bagi masyarakat kurang mampu agar mereka mampu untuk dapat melanjutkan hidup disaat mereka tidak memiliki pemasukan. Akan tetapi, sejauh ini program yang telah terlaksana adalah pemberian beras miskin (Raskin) dan ditambah lagi persebaran bantuan tersebut 
masih dirasa tidak tepat sasaran, sehingga masih banyak masyarakat miskin yang tidak mendapatkan bantuan beras miskin tersebut. Selain itu, pada hasil wawancara lainnya, ditemukan bahwa perlu adanya peningkatan kemampuan dari masyarakat di wilayah Desa Cintaratu sehingga dapat meningkatkan kesempatan dalam mendapatkan penghasilan. Berdasarkan data yang diperoleh dari Kantor Desa, penduduk Desa Cintaratu mayoritas adalah lulusan Sekolah Dasar (SD), sehingga peningkatan kemampuan sumber daya manusia di Desa Cintaratu akan menjadi suatu fondasi terhadap pembangunan Desa Cintaratu di masa yang akan datang. Selain itu, perlu juga adanya informasi terkait pentingnya pendidikan sehingga dapat memberikan pandangan bahwa dengan meningkatnya kualitas pendidikan, dapat memberikan kesempatan bagi kehidupan yang lebih baik. Hal tersebut bersumber dari hasil observasi dan wawancara yang mengungkap bahwa banyak sekali masyarakat di Desa Cintaratu yang tidak pernah membayangkan bagi anak-anaknya untuk mampu bersekolah hingga jenjang yang lebih tinggi yaitu perguruan tinggi. Namun, terungkap juga bahwa kehadiran Unpad di Desa Cintaratu meningkatkan kesadaran masyarakat bahwa pendidikan tinggi sangat penting dan juga menimbulkan harapan bagi masyarakat bahwa dengan dekatnya pendidikan tinggi di daerah mereka dapat memberikan dampak yang positif serta kesempatan bagi anak-anak mereka untuk dapat melanjutkan studi hingga tingkat universitas.

\section{SIMPULAN}

Dari hasil pengumpulan data yang diperoleh dari observasi partisipasif dan wawancara secara mendalam kepada masyarakat Desa Cintaratu, ditemukan bahwa terdapat stratifikasi secara sosial dalam memandang orang yang dianggap berpengaruh, khususnya adalah yang memiliki kedudukan di pemerintahan (dalam hal ini adalah kepala desa dan perangkat desa), tokoh keagamaan, serta orang yang dianggap memiliki tingkat ekonomi diatas rata-rata masyarakat desa. Selain itu, diketahui juga sebagian besar memiliki mata pencaharian di bidang pertanian, dan ironisnya banyak warga yang kurang mampu justru berasal dari bidang pertanian ini karena merupakan seorang buruh tani. Maka, diperlukan data lebih lanjut terkait jumlah petani di Desa Cintaratu yang merupakan pemilik lahan atau buruh tani karena belum terungkap pada penelitian ini.

Jika dilihat dari organisasi kemasyarakatan, cukup banyak organisasi kemasyarakatan yang ada di Desa Cintaratu yaitu ada 12 lembaga kemasyarakatan. Namun, masih cukup banyak yang keberadaannya justru belum terasa dampaknya oleh masyarakat seperti lembaga Pos Penyuluhan Desa (Posluh), Badan Usaha Milik Desa (Bumdes), dan Pemberdayaan Kesehatan Keluarga (PKK). Sehingga hal ini perlu menjadi perhatian bagi pengelola lembaga tersebut juga oleh Pemerintah Desa Cintaratu untuk dapat memaksimalkan keberadaan ketiga Lembaga masyarakat tersebut agar bisa memiliki program-program yang dampaknya terasa langsung oleh masyarakat. Ditinjau dari masyarakat miskin, ternyata program yang diharapkan dengan yang diterima masih belum sesuai dengan harapan masyarakat miskin tersebut. Perlu adanya peningkatan kemampuan masyarakat desa sehingga memiliki pendapatan yang lebih layak lagi.

Dari hasil pemetaan ini, masih perlu data pendukung untuk dapat dijadikan suatu rujukan dengan dilakukan penelitian lainnya. Karena cukup banyak data yang dirasa kurang lengkap seperti potensi sumber daya alam, potensi geologis, potensi budaya, serta profil masyarakat desa baik dari demografis. Dengan data yang lebih lengkap, diharapkan dapat menjadi suatu masukan yang berharga bagi Pemerintah Desa Cintaratu.

\section{DAFTAR PUSTAKA}

Badan Pusat Statistik Kabupaten Ciamis. (2019). Kabupaten Pangandaran Dalam Angka 2019. 
Bungin, B. (2007). Penelitian Kualitatif: Komunikasi, Ekonomi, Kebijakan Publik, dan Ilmu Sosial Lainnya (Vol. 2). Kencana.

Chambers, R. (1994). The Origins and Practice of Participatory Rural Appraisal. World Development, 22(7), 953-969.

Darwis, R. S., Resnawaty, R., \& Nuriyah, E. (2020). PENINGKATAN SENSITIVITAS KEPEMIMPINAN LOKAL DALAM PENGELOLAAN SUNGAI CITARUM MELALUI TEKNIK PARTICIPATORY RURAL APPRAISAL (PRA) DI DESA RANCAMANYAR. Kumawula: Jurnal Pengabdian Kepada Masyarakat, 3(1).

Handayani, S. (2009). Penerapan Metode Penelitian Participatory Research Apraisal Dalam Penelitian Permukiman Vernakular (Permukiman Kampung Kota). In Proceeding Seminar Nasional Penelitian Arsitektur-Metoda dan Penerapannya Seri (Vol. 2, p. 1).

Handoyo, P., \& Sudrajat, A. (2016). Pemetaan Sosial Untuk Perencanaan Pemberdayaan Masyarakat Desa Kemantren, Lamongan. In Seminar Nasional 2016 Mengawal Pelaksanaan SDGs (Sustainable Development Goals) (p. 595).

Miles, M. B., \& Huberman, A. M. (1994). Qualitative Data Analysis: An Expanded Sourcebook. Sage.

Sugiyono. (2008). Metode Penelitian Pendidikan: (Pendekatan Kuantitatif, Kualitatif dan R\&D). Alfabeta.

Sukoco, I., Fordian, D., \& Rusdin. (2020).

Pelatihan Dasar Dan Workshop Kewirausahaan Di Desa Cintaratu Kabupaten Pangandaran. Kumawula: Jurnal Pengabdian Kepada Masyarakat, 2(3), 248-261.

https://doi.org/10.24198/kumawula.v2i3. 24706

Strauss, A., \& Corbin, J. (2003). Penelitian Kualitatif. Yogyakarta: Pustaka Pelajar. 